\title{
HUBUNGAN LAMA HEMODIALISIS DENGAN NAFSU MAKAN PADA PASIEN GAGAL GINJAL KRONIK DI UNIT HEMODIALISIS RUMAH SAKIT GRANDMED LUBUK PAKAM TAHUN 2019
}

\section{ARFAH MAY SYARA ${ }^{1}$, SYATRIAWATI SUHAIMI ${ }^{2}$, ANITA SRI GANDARIA PURBA $^{3}$, JUNI MARIATI SIMARMATA ${ }^{4}$, CINDY YULVIKA SARAGIH ${ }^{5}$}

\author{
1,2,3,4,5 INSTITUT KESEHATAN MEDISTRA LUBUK PAKAM \\ Jalan Sudirman No. 38 Lubuk Pakam \\ amaysyara@gmail.com
}

DOI : $10.35451 / j k f . v 3 i 1.537$

\begin{abstract}
Hemodialysis patients are susceptible to malnutrition caused by components in hemodialysis, such as Dialyzer (Kidney Artificial), blood line, AV fistula, bicarbonate fluid, acidic liquid. Patients who have long been undergoing hemodialysis have high ureum and the amount of creatinine. The amount of the amount of urea and creatinine can stimulate acid production such as stomach ulcers (gastritis), namely nausea, vomiting, heartburn, bloating and no appetite. This research aims to knowing long standing relationship of hemodialysis with appetite in patients chronic renal failure in the unit hemodialysis of Grandmed Lubuk Pakam Hospital in 2019. This type of research is quantitative research, using analytical survey method with cross sectional approach. The population in this study were all patients with chronic kidney disease who were in the hemodialysis unit of Grandmed Lubuk Pakam Hospital with a sample of 49 people, using a purposive sampling technique. Data collection was using a questionnaire. The analysis in this study used Chi Square test with a degree of confidence of $5 \%=0,05$. The results of the study stated that the majority of respondents were in the old category (2 years-3 years) as many as 31 people (63.3\%) with decreased appetite by 21 people $(42.9 \%)$, fixed appetite of 7 people $(14.3 \%)$, appetite increased by 3 people $(6.1 \%)$. There was a long standing relationship of hemodialysis with appetite in patients chronic renal failure in the unit hemodialysis of Grandmed Lubuk Pakam Hospital in 2019 with $p$ value $<a=0,05$.
\end{abstract}

Keywords: Long of Hemodialysis, Appetite, Chronic Renal Failure

\section{PENDAHULUAN}

Penyakit ginjal kronis sebenarnya sudah tidak asing lagi bagi sebagian besar masyarakat. Penyakit ginjal kronis salah satu masalah yang sering terjadi di dunia yang mana prevalensinya terus meningkat, yang menyebabkan meningkatnya beban biaya kesehatan global. Meluasnya penyakit ginjal kronis, telah mencakup daerah, kabupaten, kota, bahkan Negara. Tidak hanya di negara maju saja namun di negara berkembang pun penyakit gagal ginjal kronik sudah menyebar luas. Banyak komplikasi yang diakibatkan oleh penyakit ginjal kronis seiring dengan tambahnya 
stadium yang diderita pasien semakin berat (Suwitra, 2016).

Hemodialisis salah satu terapi yang dilakukan sebagai pengganti ginjal yang sering digunakan. Pasien ginjal kronis yang menjalani hemodialisis beresiko mengalami kekurangan gizi. Beberapa faktor yang menyebabkan malnutrisi pada penderita yang dilakukan hemodialisis, yaitu peningkatan pemecahan nutrisi, berkurangnya nutrisi selama proses hemodialisis, peradangan, kormobid, tidak berfungsinya hormon, dan berkurangnya selera makan (Oliveira, 2015).

Dari kasus penyakit gagal ginjal, ada beberapa faktor risiko yang dapat mengakibatkan penyakit ginjal kronis seperti hipertensi, diabetes mellitus, pertambahan usia, riwayat keluarga, obesitas, berat badan lahir kurang, penyakit kardiovaskuler, penyakit autoimun seperti systemic lupus eritematosus, intoksikasi, infeksi yang ada dalam tubuh, infeksi perkemihan, batu ginjal dan penyakit saluran kemih (Tjekyan, 2014).

Berdasarkan data Badan Kesehatan Dunia atau World Health Organization (WHO), menyebutkan pertumbuhan jumlah penyakit ginjal kronis tahun 2016 meningkat 50\% dari tahun sebelumnya dan penderita gagal ginjal baik akut maupun kronik mencapai $50 \%$ sedangkan yang diketahui dan mendapatkan pengobatan hanya $25 \%$ dan $12,5 \%$ dengan penatalaksanaan yang baik (Indrasari, 2015).

Prevalensi ginjal kronis di Amerika Serikat berdasarkan center for disease control and prevention, pada tahun 2016 diperkirakan lebih dari $10 \%$ orang atau lebih dari 20 juta orang beresiko mengalami gagal ginjal kronik, sedangkan jumlah pasien ginjal kronis pada tahap akhir di Amerika Serikat yang menjalani pengobatan sebanyak 113, 136 penderita (Wahyu, 2017).
Indonesia termasuk negara dengan tingkat penderita ginjal kronis cukup tinggi. Penderita gagal ginjal kronik mengalami peningkatan $0,1 \%, 12 \%$ dari total penderita merupakan pasien baru GGK di Jawa Tengah (IRR, 2014). Jumlah pasien baru yang melakukan hemodialisis di Indonesia terus meningkat sejak tahun 2007 hingga 2014 secara berturut-turut sebanyak 4.977, 5.392, 8.193, 9.649, 15.353, $19.621,15.128$, dan 17.193 orang (Indonesia Renal Registry, 2014).

Berdasarkan Riskesdas tahun 2013, prevalensi gagal ginjal kronis berdasarkan diagnosis dokter di Indonesia sebesar 0,2\%. Prevalensi tertinggi di Sulawesi Tengah sebesar 0,5\%, diikuti Aceh, Gorontalo, dan Sulawesi Utara masing-masing 0,4\%. Sementara Nusa Tenggara Timur, Sulawesi Selatan, Lampung, Jawa Barat, Jawa Tengah, DI Yogyakarta, dan Jawa Timur masing-masing 0,3\%. Provinsi Sumatera Utara sebesar 0,2\% (Kemenkes RI, 2015).

Berdasarkan data dari Dinas Kesehatan Sumatera Utara, pada tahun 2014 di provinsi Sumatera Utara tercatat pasien ginjal kronis berjumlah 2.608 jiwa dengan jumlah penderita terbanyak pada usia di atas 55 tahun dan paling banyak terjadi pada yang berjenis kelamin laki-laki (Kemenkes RI, 2015).

Di Sumatera Utara, berdasarkan hasil survey peneliti pada tanggal 15 Januari 2016 di Rumah Sakit Umum Pusat H. Adam Malik Medan diketahui tahun 2013 dari bulan Januari sampai Desember didapatkan penderita GGK sebanyak 761 orang dengan banyak pasien di ruangan Hemodialisis sebanyak 641 kunjungan. Pada tahun 2014 pada bulan Januari sampai Desember didapatkan penderita GGK sebanyak 470 orang dengan jumlah kujungan di ruangan hemodialisis sebanyak 9.958 kunjungan. Pada tahun 
2015 dari Januari sampai Desember didapatkan data penderita GGK sebanyak 249 orang dengan banyaknya pasien yang melakukan hemodialisis sebanyak 3.361 kunjungan (Rumah Sakit. H. Adam Malik, 2016).

Hemodialisis yang berkepanjangan mengakibatkan infeksi pada lambung yang mengakibatkan peningkatan asam amino pada lambung sehingga pasien dengan gagal ginjal kronik mengakibatkan selera makan berkurang bahkan kehilangan bobot tubuh yang cukup signifikan (Suharyanto \& Madjid, 2013).

Penderita ginjal kronis yang sudah lama melakukan terapi hemodialisis akan mempunyai nilai ureum dan kreatinin yang tinggi. Ureum yang meningkat akan menghambat produksi dari hormon eritropoietin. Mengakibatkan sel darah merah menurun atau disebut anemia. Sehingga pasien menjadi lemah, lesu, dan letih yang merupakan tanda kelelahan (Suharyanto dan Madjid, 2013). Berdasarkan hasil penelitian yang dilakukan pada 174 responden tentang waktu hemodialisis dengan berkurangnya nafsu makan pada pasien gagal ginjal kronik di unit hemodialisis RSUD Ulin Banjarmasin didapatkan hasil bahwa sebagian besar responden yang cukup lama (1-3 tahun) yang menjalani hemodialisis sebanyak 96 orang $(55,2 \%)$, sebagian besar responden didapatkan mengalami penurunan selera makan berat sebanyak 114 orang $(65,5 \%)$. Hal yang sama juga dilaporkan Wirhan A, dkk pada tahun 2014, yang meneliti perubahan gizi pada 41 orang penderita PGK yang menjalani hemodialisis, dimana malnutrisi berkisar antara 30\%-77,8\%, tergantung kriteria penilaian status gizi. Dengan skin fold, malnutrisi didapatkan sebesar $41,7 \%$, sementara dengan LILA didapatkan $55,6 \%$.
Berdasarkan srvey awal yang dilakukan peneliti tiga bulan terakhir di tahun 2018, yaitu bulan Desember dan tahun 2019 yaitu, bulan Januari dan Februari, diperoleh data sebanyak 150 pasien ginjal kronis yang melakukan hemodialisis di ruang Hemodialisa Rumah Sakit Grandmed Lubuk Pakam. Banyaknya pasien yang mengalami ginjal kronis dan menjalani terapi hemodialisis dari data per tiga bulan pada tahun 2018 dan 2019, yang didapatkan oleh peneliti di Rumah Sakit Grandmed Lubuk Pakam mulai dari usia 30 tahun ke atas dengan jumlah penderita yang melakukan hemodialisa sebanyak 49 orang, dengan frekuensi menjalani hemodialisis yang berbedabeda mulai dari singkat ( 6 bulan -1 tahun) berjumlah 14 orang dengan jumlah laki-laki sebanyak 10 orang dan pada perempuan sebanyak 4 orang. Dan lama (2 tahun-3 tahun) berjumlah 35 orang dengan laki-laki sebanyak 20 orang dan perempuan sebanyak 15 orang.

Berdasarkan hasil wawancara singkat yang dilakukan peneliti pada pasien yang melakukan terapi hemodialisa di Rumah Sakit Grandmed Lubuk Pakam, pasien mengatakan setelah menjalani terapi hemodialisis terjadi perubahan nafsu makan pasien, ada yang meningkat, menurun bahkan tetap atau stabil.

Berdasarkan masalah tersebut, peneliti ingin melakukan penelitian tentang "Hubungan Lama Hemodialisis Dengan selera Makan Pada Pasien Chronic Kidney Disease Di Ruang Hemodialisis Rumah Sakit Grandmed Lubuk Pakam Tahun 2019".

\section{METODE PENELITIAN}

Jenis penelitian ini merupakan penelitian kuantitatif, dengan metode survey analitik dan pendekatan cross sectional, dengan tujuan untuk mengetahui hubungan lama 
hemodialisis dengan selera makan pada pasien Chronic Kidney Disease di Ruang Hemodialisis Rumah Sakit Grandmed Lubuk Pakam. Populasi kasus adalah seluruh penderita ginjal kronis yang berada di unit hemodialisis rumah sakit Grandmed Lubuk Pakam sebanyak 150 orang di Unit Hemodialisis Rumah Sakit Grandmed Lubuk Pakam. Sampel dalam penelitian ini dengan purposive sampling berjumlah 49 orang.

\section{HASIL PENELITIAN}

1. Gambaran Lamanya Hemodialisis pada pasien Gagal Ginjal Kronik di Unit Hemodialisis Rumah Sakit Grandmed Lubuk Pakam

Adapun gambaran lamanya waktu hemodialisis pada penderita Gagal Ginjal Kronik di Unit Hemodialisis Rumah Sakit Grandmed Lubuk Pakam diperoleh berdasarkan hasil penelitian pada tabel berikut:

Tabel 1. Distribusi Responden Berdasarkan Lama Hemodialisis pada

Pasien Gagal Ginjal Kronik yang Menjalani Hemodialisis.

\begin{tabular}{cccc}
\hline No & $\begin{array}{c}\text { Lama } \\
\text { Hemodialisis }\end{array}$ & $\begin{array}{c}\text { Frekuensi } \\
\text { (Orang) }\end{array}$ & $\begin{array}{c}\text { Persentase } \\
\mathbf{( \% )}\end{array}$ \\
\hline 1 & $\begin{array}{c}\text { Singkat } \\
\text { (6 bulan - } \\
1 \text { tahun) }\end{array}$ & 18 & 36.7 \\
\cline { 2 - 4 } 2 & $\begin{array}{c}\text { Lama } \\
(2 \text { tahun }- \\
3 \text { tahun })\end{array}$ & 31 & 63.3 \\
\cline { 2 - 4 } & Total & $\mathbf{4 9}$ & $\mathbf{1 0 0}$ \\
\hline
\end{tabular}

Berdasarkan Tabel 1 diketahui bahwa jumlah responden berdasarkan lama hemodialisis singkat ( 6 bulan - 1 tahun) sebanyak 18 orang $(36,7 \%)$, jumlah responden lama ( 2 tahun - 3 tahun) sebanyak 31 orang $(63,3 \%)$.

2. Gambaran Selera Makan pada pasien Ginjal Kronis di Unit Hemodialisis Rumah Sakit Grandmed Lubuk Pakam
Adapun gambaran keinginan makan pada pasien Gagal Ginjal di Unit Rumah Sakit Grandmed Lubuk Pakam dperoleh berdasarkan hasil penelitian pada tabel berikut:

Tabel 2. Distribusi Responden Berdasarkan Nafsu Makan pada Pasien Gagal Ginjal Kronik yang Menjalani Hemodialisis

\begin{tabular}{llcc}
\hline No & $\begin{array}{l}\text { Nafsu } \\
\text { Makan }\end{array}$ & $\begin{array}{c}\text { Frekuensi } \\
\text { (Orang) }\end{array}$ & $\begin{array}{c}\text { Persentase } \\
\mathbf{( \% )}\end{array}$ \\
\hline 1 & Menurun & 26 & 53.1 \\
\cline { 2 - 4 } 2 & Tetap & 16 & 32.7 \\
\cline { 2 - 4 } 3 & Meningkat & 7 & 14.3 \\
\cline { 2 - 4 } & Total & $\mathbf{4 9}$ & $\mathbf{1 0 0}$ \\
\hline
\end{tabular}

Berdasarkan Tabel 2 diketahui bahwa jumlah responden berdasarkan nafsu makan menurun sebanyak 26 orang $(53,1 \%)$, nafsu makan tetap sebanyak 16 orang $(32,7 \%)$, nafsu makan meningkat sebanyak 7 orang $(14,3 \%)$.

\section{Analisa Bivariat}

Adapun hubungan lamanya hemodialisis dengan selera makan pada pasien Gagal Ginjal di Unit Hemodialisis Rumah Sakit Grandmed Lubuk Pakam berdasarkan hasil penelitian pada tabel berikut:

Tabel 3. Hubungan Lama Hemodialisis Dengan Nafsu Makan Pada Pasien Gagal Ginjal Kronik Di Unit Hemodialisis Rumah Sakit Grandmed Lubuk Pakam

Tahun 2019

\begin{tabular}{|c|c|c|c|c|c|c|}
\hline \multirow{3}{*}{$\begin{array}{c}\text { Lama } \\
\text { Hemo } \\
\text { Dia } \\
\text { lisis }\end{array}$} & \multicolumn{5}{|c|}{ Nafsu Makan } & \multirow{3}{*}{$\begin{array}{c}p \\
\text { Valu } \\
e\end{array}$} \\
\hline & \multirow{2}{*}{$\begin{array}{c}\begin{array}{c}\text { Menu } \\
\text { run }\end{array} \\
\mathbf{n} \\
\%\end{array}$} & \multirow{2}{*}{$\begin{array}{c}\text { Tetap } \\
\mathbf{n} \\
\%\end{array}$} & \multicolumn{2}{|c|}{$\begin{array}{c}\text { Mening } \\
\text { kat }\end{array}$} & \multirow{2}{*}{$\begin{array}{l}\text { To } \\
\text { Tal } \\
\mathbf{n} \\
\%\end{array}$} & \\
\hline & & & $\mathbf{n}$ & $\%$ & & \\
\hline $\begin{array}{l}\text { Singka } \\
\mathrm{t} \quad(6 \\
\text { bulan } \\
-\quad 1 \\
\text { tahun) }\end{array}$ & $\begin{array}{c}5 \\
10,2\end{array}$ & $\begin{array}{c}9 \\
18,4\end{array}$ & 4 & 8,2 & $\begin{array}{l}18 \\
36,7\end{array}$ & \\
\hline $\begin{array}{l}\text { Lama } \\
\text { ( } 2 \\
\text { tahun } \\
-\quad 3 \\
\text { tahun) }\end{array}$ & $\begin{array}{c}21 \\
42,9\end{array}$ & $\begin{array}{c}7 \\
14,3\end{array}$ & 3 & 6,1 & $\begin{array}{l}31 \\
63,3\end{array}$ & 0,05 \\
\hline Total & $\begin{array}{c}26 \\
53,1\end{array}$ & $\begin{array}{l}16 \\
32,7\end{array}$ & 7 & 14,3 & $\begin{array}{c}49 \\
100\end{array}$ & \\
\hline
\end{tabular}


Berdasarkan Tabel 3 dapat diketahui bahwa dari lama hemodialisis singkat ( 6 bulan - 1 tahun) sebanyak 18 orang $(36,7 \%)$, dengan nafsu makan menurun sebanyak 5 orang $(10,2 \%)$, nafsu makan tetap sebanyak 9 orang $(18,4 \%)$, nafsu makan meningkat sebanyak 4 orang (8,2\%). Lama hemodialisis lama ( 2 tahun - 3 tahun) sebanyak 31 orang $(63,3 \%)$, dengan nafsu makan menurun sebanyak 21 orang $(42,9 \%)$, nafsu makan tetap sebanyak 7 orang $(14,3 \%)$, nafsu makan meningkat sebanyak 3 orang $(6,1 \%)$.

Berdasarkan hasil analisa dengan menggunakan uji Chi Square dengan nilai $p$ value $=0,05$, yang artinya ha diterima yang berarti ada hubungan antara lama hemodialisis dengan nafsu makan pada pasien gagal ginjal kronik di unit hemodialisis Rumah Sakit Grandmed Lubuk Pakam Tahun 2019.

\section{PEMBahasan}

1. Lama Hemodialisis

Berdasarkan Tabel 1 diketahui bahwa jumlah penderita menurut waktu hemodialisa singkat ( 6 bulan-1 tahun) sebanyak 18 orang $(36,7 \%)$, jumlah responden lama ( 2 tahun - 3 tahun) sebanyak 31 orang $(63,3 \%)$.

Hasil penelitian ini didapatkan pasien yang sudah menjalani terapi hemodialisis lebih banyak 2 tahun - 3 tahun yaitu sebanyak 31 orang (63\%). $\mathrm{Hal}$ ini didukung oleh penelitian sebelumnya pasien dengan lama hemodialisis $>1$ tahun sebanyak 37 orang $(63,8 \%)$ dibandingkan dengan lama hemodialisis $\leq 1$ tahun sebanyak 21 orang $(36,2 \%)$ (Chertow, 2006).

Berdasarkan penelitian yang dilakukan, asumsi peneliti yaitu dengan sampel sebanyak 49 orang. peneliti mengelompokkan berdasarkan umur dan jenis kelamin pada responden. Hasil penelitian yang didapatkan lebih banyak pasien menjalani hemodialisis yang sudah lama dibandingkan pasien yang baru menjalani hemodialisis.

\section{Nafsu Makan}

Berdasarkan Tabel 2 diketahui bahwa jumlah responden berdasarkan nafsu makan menurun sebanyak 26 orang $(53,1 \%)$, nafsu makan tetap sebanyak 16 orang $(32,7 \%)$, nafsu makan meningkat sebanyak 7 orang $(14,3 \%)$.

Hasil penelitian sebelumnya responden yang mengalami nafsu makan kurang sebanyak 34 orang $(58,6 \%)$ dan nafsu makan baik sebanyak 24 orang (41,4\%). Dengan adanya retensi uremia, sitokin proinflamasi, gangguan hormonal dan neuropeptida menyebabkan terjadinya Penurunan nafsu makan (Carerro, 2009).

Berdasarkan penelitian yang dilakukan asumsi peneliti yaitu peneliti mengkategorikan nafsu makan menjadi nafsu makan menurun, nafsu makan yang tetap dan nafsu makan yang meningkat. Hasil penelitian yang didapatkan pada pasien gagal ginjal kronik di unit hemodialisis Rumah Sakit Grandmed Lubuk Pakam Tahun 2019 yaitu nafsu makan menurun lebih banyak terjadi, dibandingkan dengan nafsu makan tetap dan nafsu makan meningkat.

3. Hubungan Lama Hemodialisis Dengan Selera Makan Pada Pasien Gagal Ginjal Kronik di Unit Hemodialisis Rumah Sakit

Grandmed Lubuk Pakam

Berdasarkan Tabel 3 dapat diketahui bahwa dari lama hemodialisis singkat ( 6 bulan - 1 tahun) sebanyak 18 orang $(36,7 \%)$, dengan nafsu makan menurun sebanyak 5 orang $(10,2 \%)$, nafsu makan tetap sebanyak 9 orang $(18,4 \%)$, nafsu makan meningkat sebanyak 4 orang $(8,2 \%)$. 
Lama hemodialisis lama ( 2 tahun - 3 tahun) sebanyak 31 orang $(63,3 \%)$, dengan nafsu makan menurun sebanyak 21 orang $(42,9 \%)$, nafsu makan tetap sebanyak 7 orang $(14,3 \%)$, nafsu makan meningkat sebanyak 3 orang $(6,1 \%)$.

Hasil penelitian menyatakan bahwa mayoritas responden berada pada kategori lama hemodialisis lama (2 tahun-3 tahun) sebanyak 31 orang $(63,3 \%)$ dengan nafsu makan menurun sebanyak 21 orang (42,9\%), nafsu makan tetap sebanyak 7 orang $(14,3 \%)$, nafsu makan meningkat sebanyak 3 orang $(6,1 \%)$.

Hasil penelitian sebelumnya dari 174 orang responden diketahui bahwa dengan penurunan nafsu makan ringan sebanyak 31 orang pasien yang baru saja menjalani hemodialisis $(79,5 \%)$, pasien dengan penurunan nafsu berat sebanyak 79 orang $(82,3 \%)$ yang cukup lama menjalani hemodialisis, dan pasien dengan penurunan nafsu berat sebanyak 35 orang $(89,7 \%)$ yang sangat lama menjalani hemodialisis. Hasil analisis dengan uji Chi Square diperoleh hasil bahwa nilai $p=0,000$ dapat dikatakan bahwa ada hubungan lamanya hemodialisis dengan penurunan nafsu makan pada pasien gagal ginjal kronik di unit hemodialisis RSUD Ulin Banjarmasin.

Berdasarkan hasil analisa data didapatkan bahwa terdapat hubungan antara lamanya hemodialisis dengan nafsu makan pada pasien gagal ginjal kronik di unit hemodialisis Rumah Sakit Grandmed Lubuk Pakam Tahun 2019.

\section{KESIMPULAN DAN SARAN}

1. Kesimpulan

Pada pasien gagal ginjal kronik berdasarkan lama hemodialisis singkat ( 6 bulan-1 tahun) sebanyak 18 orang $(36,7 \%)$, jumlah responden lama (2 tahun - 3 tahun) sebanyak 31 orang (63,3\%). Nafsu makan menurun sebanyak 26 orang $(53,1 \%)$ pada pasien gagal ginjal kronik, nafsu makan tetap sebanyak 16 orang $(32,7 \%)$, nafsu makan meningkat sebanyak 7 orang $(14,3 \%)$. Terdapat hubungan lamanya hemodialisis dengan nafsu makan pada pasien gagal ginjal kronik di unit hemodialisis Rumah Sakit Grandmed Lubuk Pakam Tahun 2019 dengan $p$ value $=0,05$.

2. Saran

Diharapkan agar pasien dapat menerima perubahan-perubahan yang terjadi pada dirinya termasuk pada perubahan dari nafsu makannya. Diharapkan perawat hemodialisis memberikan pendidikan kesehatan kepada keluarga pasien untuk lebih meningkatkan dukungan yang baik terhadap depresi yang dialami dengan penyakitnya. Hasil penelitian sebagai masukan dan sumber informasi serta dapat melakukan penyuluhan kesehatan tentang pasien yang menjalani terapi hemodialisis mengalami perubahan diantaranya yaitu perubahan pada nafsu makan pasien. Hasil penelitian ini agar dapat dijadikan sebagai bahan tambahan informasi dan sebagai bacaan di perpustakaan Institut Kesehatan MEDISTRA Lubuk Pakam. Dan disarankan pada penelitian selanjutnya agar meneliti lebih lanjut mengenai lamanya hemodialisis dengan nafsu makan pada pasien gagal ginjal kronik serta kejadian penurunan nafsu makan berdasarkan karakteristik pasien yang lebih banyak.

\section{DAFTAR PUSTAKA}

Bayhakki. 2013. Peningkatan Kualitas Hidup Pada Penderita Gagal Ginjal Kronik Yang Menjalani Terapi Hemodialisa Melalui Psychological Intervention Di Unit Hemodialisa RS Royal Prima Medan Tahun 2016. Journal Jumantik. 2(1). 
Fikri, Yusuf. 2012. Hubungan Asupan Protein Dengan Kadar Ureum, Kreatinin, dan Kadar Hemoglobin Darah pada Penderita Gagal Ginjal Kronik Hemodialisa Rawat Jalan Di RS Tugurejo Semarang. JournalGizi. $3(1)$.

Hayani. 2014. Peningkatan Kualitas Hidup Pada Penderita Gagal Ginjal Kronik Yang Menjalani Terapi Hemodialisa Melalui Psychological Intervention Di Unit Hemodialisa RS Royal Prima Medan Tahun 2016. Journal Jumantik. 2(1).

Hidayat. 2014. Metode Penelitian dan Keperawatan Dan Teknis Analisis Data. Jakarta : Salemba.

Hirmawaty. 2014. Peningkatan Kualitas Hidup Pada Penderita Gagal Ginjal Kronik Yang Menjalani Terapi Hemodialisa Melalui Psychological Intervention Di Unit Hemodialisa RS Royal Prima Medan Tahun 2016. Journal Jumantik. 2(1).

Indonesia Renal Registry (IRR). 2014. Report of Indonesian Renal Registry. Perhimpunan Nefrologi Indonesia.

Indrasari. 2015. Peningkatan Kualitas Hidup Pada Penderita Gagal Ginjal Kronik Yang Menjalani Terapi Hemodialisa Melalui Psychological Intervention Di Unit Hemodialisa RS Royal Prima Medan Tahun 2016. Journal Jumantik. 2(1).

Insel. 2010. Faktor-Faktor Yang Berhubungan Dengan Nafsu Makan Kurang Pada Pasien hemodialisis Di RSPAD Gatot Soebroto Tahun 2012. Skripsi. Universitas Indonesia.

Mardyaningsih. 2014. Peningkatan Kualitas Hidup Pada Penderita Gagal Ginjal Kronik Yang Menjalani Terapi Hemodialisa Melalui Psychological Intervention Di Unit Hemodialisa RS Royal Prima Medan Tahun 2016. Journal Jumantik. 2(1).

Muttaqin dan Sari. 2011. Faktor-Faktor Risiko Kejadian Gagal Ginjal Kronik
(GGK) Di Ruang Hemodialisa (HD) RSUP H. Adam Malik Medan. Journal, Medan.

Notoatmodjo. 2015. Metodologi Penelitian Kesehatan. Jakarta : Rineka Cipta.

Nursalam. 2015. Konsep dan Penerapan Metodologi Penelitian Ilmu Keperawatan. Jakarta : Salemba Medika.

Oliveira. 2015. Faktor-Faktor Yang Berhubungan Dengan Penurunan Nafsu Makan Pada Pasien Gagal Ginjal Kronik Yang Menjalani Terapi Hemodialisis. Journal Gipas. 1(1).

Prabowo. 2014. Peningkatan Kualitas Hidup Pada Penderita Gagal Ginjal Kronik Yang Menjalani Terapi Hemodialisa Melalui Psychological Intervention Di Unit Hemodialisa RS Royal Prima Medan Tahun 2016. Journal Jumantik. 2(1).

Riset Kesehatan Daerah. 2013. Pusat Data Dan Informasi Jawa Timur. Jawa Timur.

Riset Kesehatan Daerah. 2015. Pusat Data Dan Informasi Sumatera Utara. Sumatera Utara.

Robinson. 2013. Peningkatan Kualitas Hidup Pada Penderita Gagal Ginjal Kronik Yang Menjalani Terapi Hemodialisa Melalui Psychological Intervention Di Unit Hemodialisa RS Royal Prima Medan Tahun 2016. Journal Jumantik. 2(1).

Rustina, 2012. Hubungan antara lama menjalani hemodialisa dengan depresi pada pasien dengan sakit ginjal kronik.portalgaruda.org

Sastroasmoro. 2017. Dasar-Dasar Metodologi Penelitian Klinis. Jakarta : Sagung Seto.

Smeltzer dan Bare. 2012. Hubungan lama Hemodialisa Dengan Penurunan Nafsu Makan Pada Pasien Gagal Ginjal Kronik Di Unit Hemodialisa RSUD Ulin Banjarmasin. Journal Dinamika Kesehatan. 7(1). 
Suharyanto dan Madjid. 2013. Hubungan Lama Hemodialisa Dengan Penurunan Nafsu Makan Pada Pasien Gagal Ginjal Kronik Di Unit Hemodialisa RSUD Ulin Banjarmasin. Journal Dinamika Kesehatan. 7(1).

Suharyanto dan Madjid. 2017. Asuhan Keperawatan Pada Klien dengan Gangguan Sistem Perkemihan. Jakarta : TIM.

Suneja. 2010. Faktor-Faktor Yang Berhubungan Dengan Nafsu Makan Kurang Pada Pasien hemodialisis Di RSPAD Gatot Soebroto Tahun 2012. Skripsi. Universitas Indonesia.

Suwitra. 2016. Kualitas Hidup Pasien Gagal Ginjal Kronik Yang Menjalani Hemodialisa. Journal Psikologi. 11(1).

Tjekyan. 2014. Faktor-Faktor Risiko Kejadian Gagal Ginjal Kronik (GGK) Di Ruang Hemodialisa (HD) RSUP $H$. Adam Malik Medan. Journal, Medan.

Vorvick. 2010. Faktor-Faktor Yang Berhubungan Dengan Nafsu Makan Kurang Pada Pasien hemodialisis Di RSPAD Gatot Soebroto Tahun 2012. Skripsi. Universitas Indonesia.

Wahyu. 2017. Kualitas Hidup Pasien Gagal Ginjal Kronik Yang Menjalani Terapi Hemodialisa. Journal, Yogyakarta.

Wibowo, Yudhi. 2014. Keperawatan Medikal bedah Manajemen klinis untuk hasil yang diharapkan. Indonesia: Salemba Medika. 